
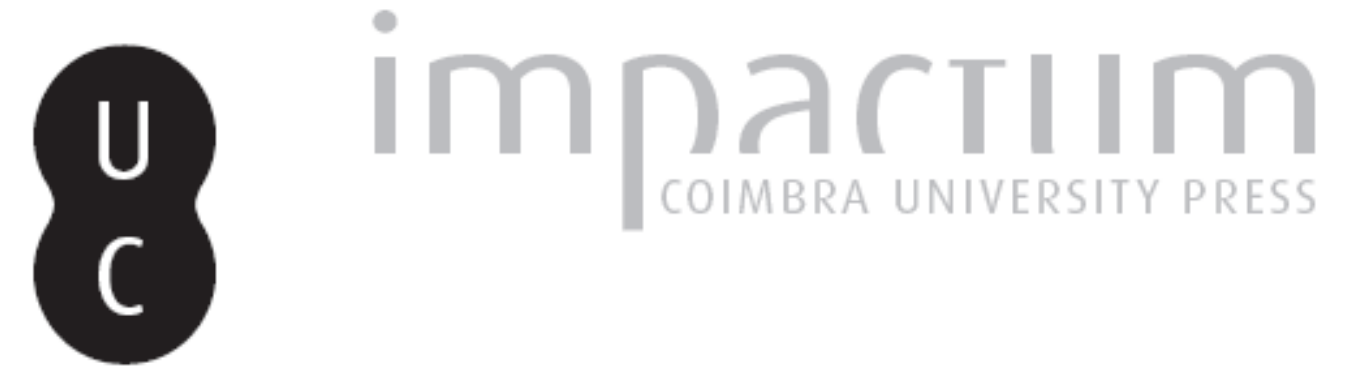

Notes towards a project for the quarries landscape of the Estremoz Anticline

Autor(es): Baganha, Pedro

Publicado por: Editorial do Departamento de Arquitetura

URL persistente:

URI:http://hdl.handle.net/10316.2/39956

DOI:

DOI:https://doi.org/10.14195/1647-8681_6_22

Accessed : $\quad$ 26-Apr-2023 10:45:02

A navegação consulta e descarregamento dos títulos inseridos nas Bibliotecas Digitais UC Digitalis, UC Pombalina e UC Impactum, pressupõem a aceitação plena e sem reservas dos Termos e Condições de Uso destas Bibliotecas Digitais, disponíveis em https://digitalis.uc.pt/pt-pt/termos.

Conforme exposto nos referidos Termos e Condições de Uso, o descarregamento de títulos de acesso restrito requer uma licença válida de autorização devendo o utilizador aceder ao(s) documento(s) a partir de um endereço de IP da instituição detentora da supramencionada licença.

Ao utilizador é apenas permitido o descarregamento para uso pessoal, pelo que o emprego do(s) título(s) descarregado(s) para outro fim, designadamente comercial, carece de autorização do respetivo autor ou editor da obra.

Na medida em que todas as obras da UC Digitalis se encontram protegidas pelo Código do Direito de Autor e Direitos Conexos e demais legislação aplicável, toda a cópia, parcial ou total, deste documento, nos casos em que é legalmente admitida, deverá conter ou fazer-se acompanhar por este aviso. 


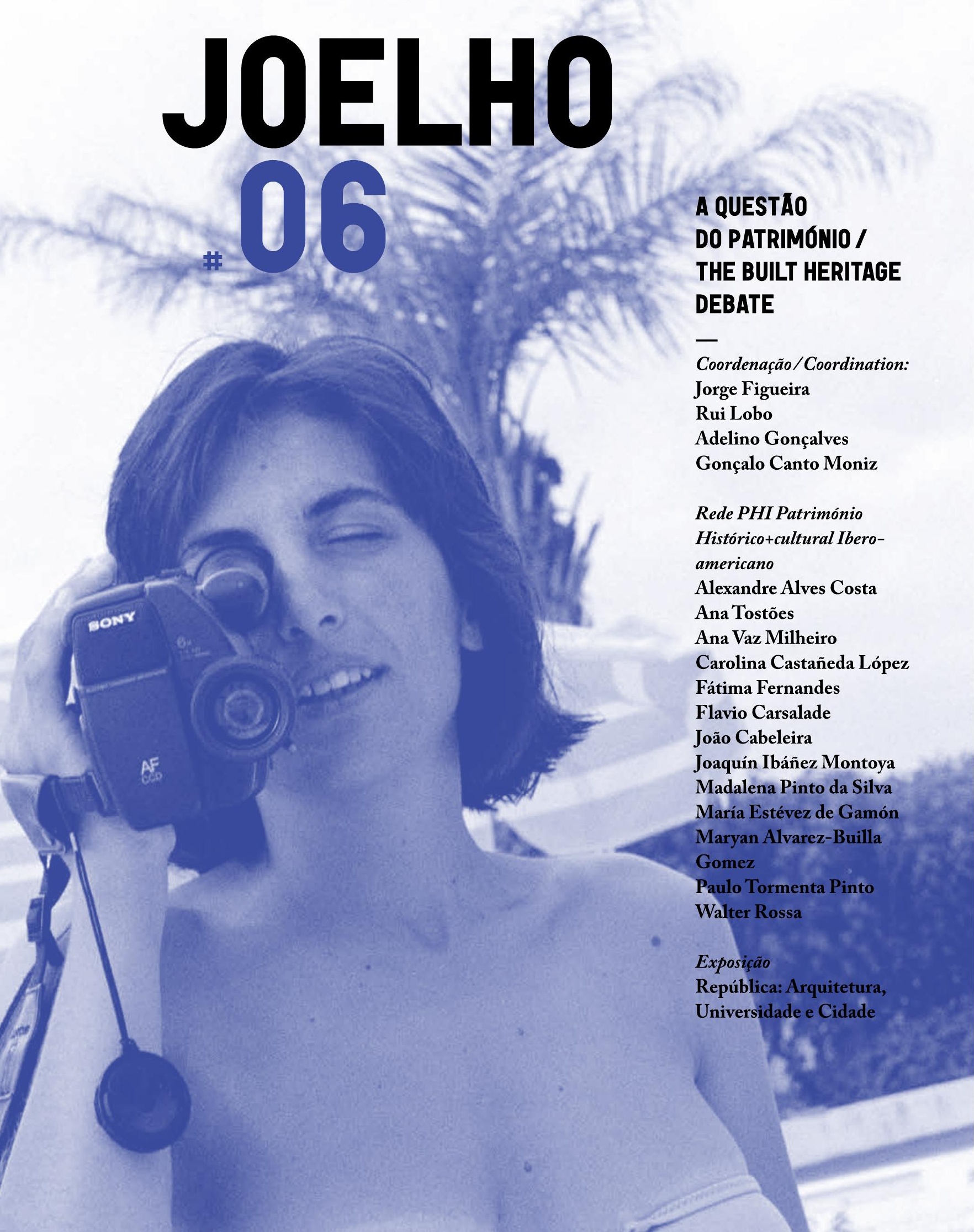




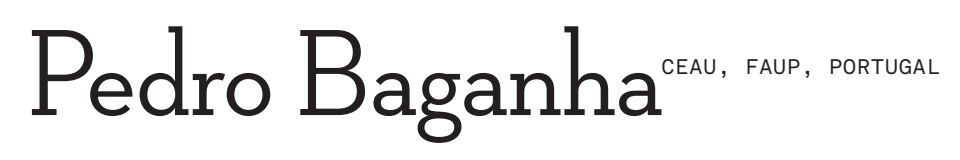

Notes towards a project

for the quarries landscape

of the Eistremoz Anticline

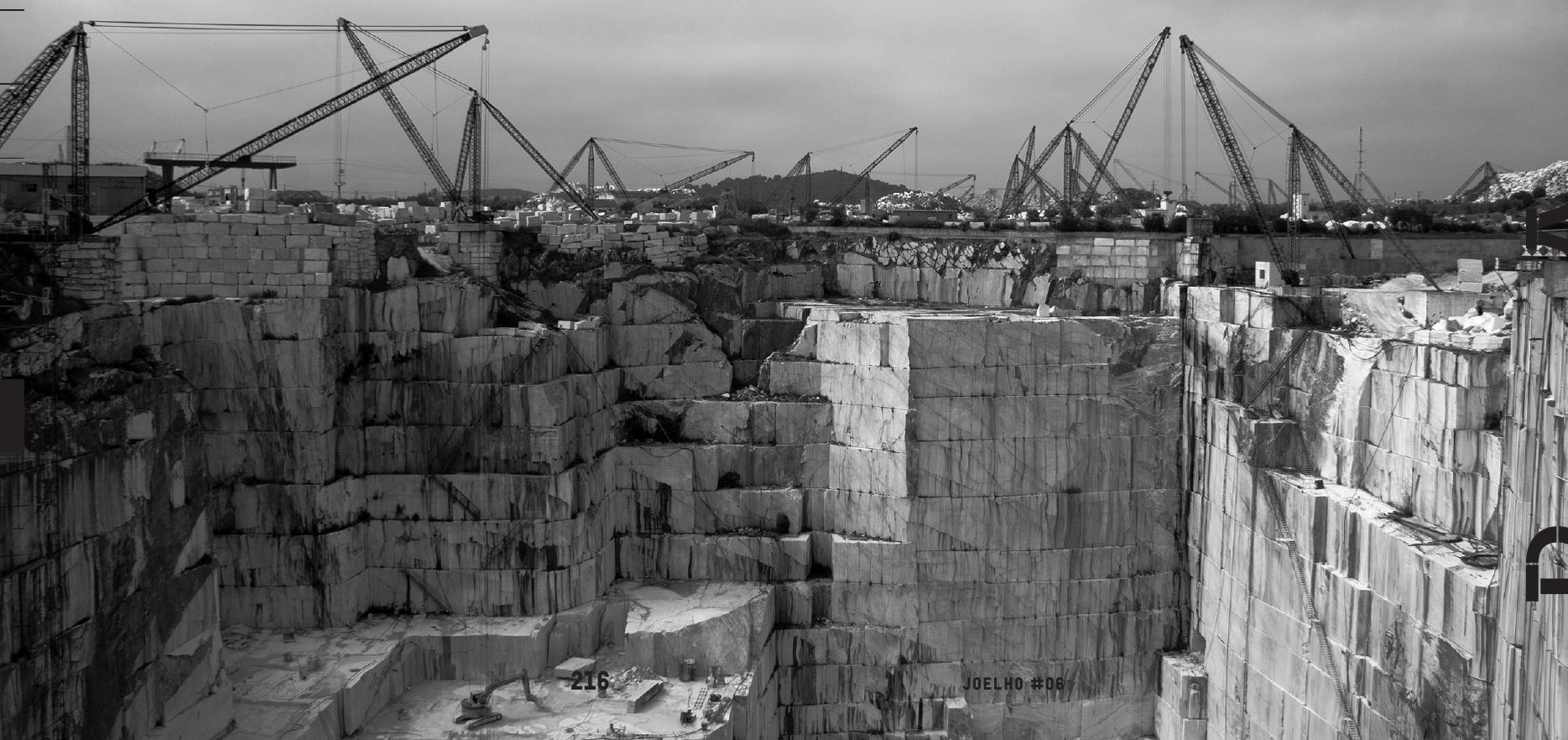




\section{The Anticline}

The largest marble explorations of Portugal are located in Estremoz Anticline, roughly 50 kilometers northeast of the city of Évora. This geographical feature extends in a northwest-southeast direction, intersecting the municipalities of Sousel, Estremoz, Borba, Vila Viçosa and Alandroal. The quarries only exist in the three central municipalities of the anticline: Estremoz, Borba, and especially, in Vila Viçosa.

The region lies on the boundary between the basins of the rivers Guadiana and Tagus, and is characterized by vast rolling plains dominated by the elevations of the anticline and the Ossa hills in the Southwest. With the exception of that mountain range, the local terrain has relatively gentle slopes.

Alentejo is well known to be a region with long and hot summers, where the control of the water cycles was always crucial in the livelihoods of their populations. The water in the anticline area is abundant, as part of it is located over a large aquifer, the EstremozCano System. That characteristic favored a land use in which small farms, orchards and vegetable gardens are predominant, causing a particular landscape contrasting with its surroundings, dominated by forestry and rainfed agriculture.

The richness of the soil and the abundance of groundwater caused a specific agricultural activity, with an occupation of the territory that can be considered atypical in Alentejo. Albeit the concentrated urban morphology of each individual settlement surrounding the anticline is typical of the region, the dispersion of its distribution in a dense urban network, interconnected by an equally dense road network, is not.

\section{The Anticline quarries}

Although the geographical specificities already described may individualize the landscape of Estremoz Anticline, its most distinctive feature is the extreme artificialization of the land caused by hundreds of marble quarries over centuries of exploitation. The marble quarrying in this area is ancient, with evidences tracing the activity back to the roman period (cf. Maciel, 1998). Currently the anticline quarries are the largest production center of ornamental rocks in the country (cf. Moura et al., 2007, p.176), with international relevance due to its scale and the volume and quality of the extracted material.

The typology of the operation, with open air quarries that reach a maximum depth of 150 meters, caused a radical transformation of the land, especially in the last 50 years. The continuous industrial activity resulted in extremely deep depressions with vertical walls of white, pink and green marble, alongside huge heaps of commercial inadequate stones and slag. Although these last landscape features constitute an environmental problem that must be mitigated, those other geological negatives, true sculptural and sublime voids of cyclopean scale, have an undeniable scientific and aesthetic value. The violent cutting of the terrain caused by the mining activity enables unique geological 


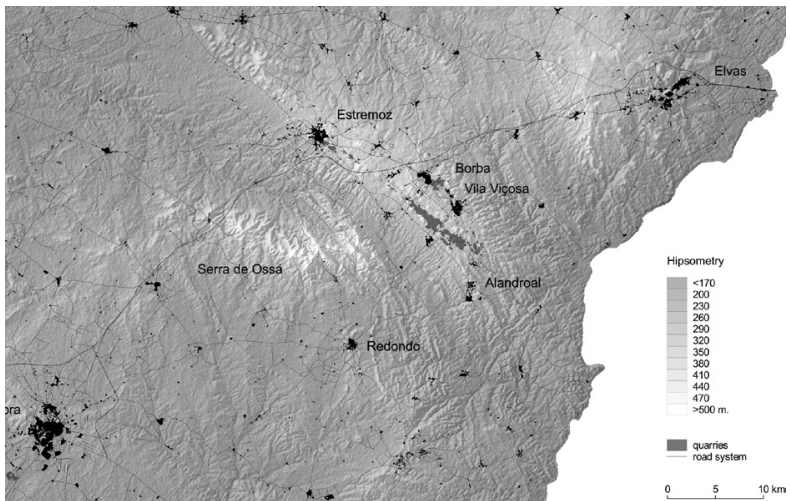

2. Hypsometry: east central Alentejo

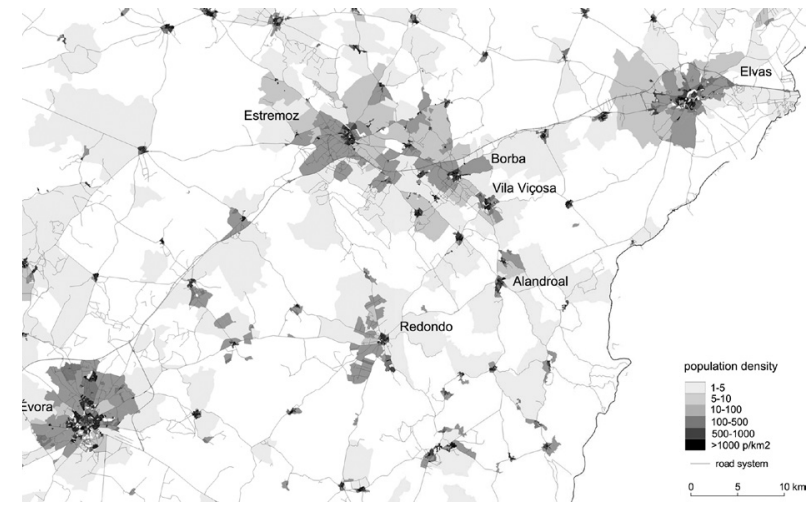

3. Population density: east central Alentejo

readings, making the area particularly suitable for its inscription as a scientific cultural site.

The location of the quarries is obviously bound to the presence of the mineral resource that is to be exploited, thus the geological knowledge of the area is an essential condition for the commercial success of the activity. However, in the case of Estremoz Anticline, this knowledge only recently reached the necessary detail for the proper planning and rationalization of the mining activity, which resulted in decades of uncontrolled exploitation and a set of environmental and scenic liabilities. Given the depth of the excavation the water table is frequently intersected, which involves the constant plumping in the majority of the active quarries. Several others, abandoned, end up completely flooded, forming a series of unusual artificial lakes, spontaneously colonized by endogenous plant species and birds that nest there.

The acknowledgement of the environmental and economic issues that arose because of the quarrying activity led to the development of a regional plan (PROZOM), in force between 2002 and 2010, which took the mitigation of those problems as its main purpose. In its conceptual framework, the specificity of the site was always seen as a disastrous consequence of the mining activity, tolerated only because of its economic relevance.

Despite the recognition of the disadvantages that the lack of planning still causes, the way the quarries problem is addressed has been undergoing a gradual paradigm shift, particularly among the social sciences. The mining landscape of Estremoz Anticline is gradually being considered a testimonial of an industrial activity of particular significance, resulting from the hard labor of generations of workers, and susceptible to be framed as a cultural, living and dynamic heritage.

In our opinion such paradigm shift should also occur in the way architecture deals with the problem. The conceptual framework should move away from the shear technical and ecological point of view that has characterized most disciplinary approaches so far, and should focus on the concepts of industrial, geological, and landscape heritage. In 


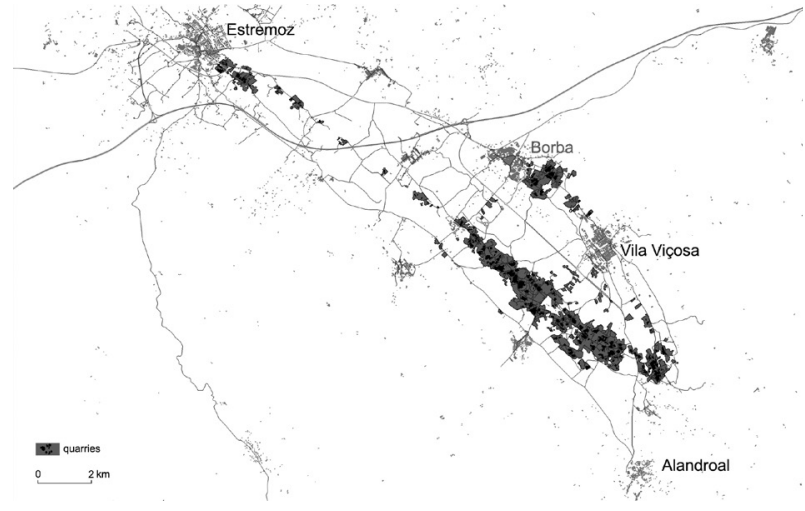

4. Local territorial structure

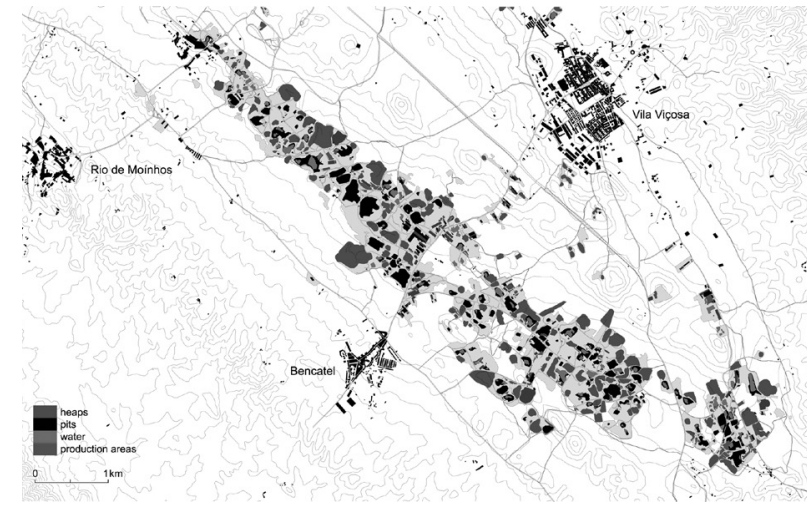

5. Vila Viçosa quarries: land use

this sense the redefinition of this territory as a cultural site integrated in an urban network and a local community should contribute to the revision of the concepts of landscape and heritage that it invokes. It is therefore necessary a landscape construction process that meets the physical dimension but also addresses the conceptual problem. Such process should focus less on trying to design a specific formal solution, and more on having a strategic and systemic approach that deals with a certain amount of indeterminacy and can lead to the establishment of a dynamic and open territorial infrastructure, alongside a new critical positioning regarding this landscape.

Such process should rely on the analysis of significant similar examples as a way to validate a programmatic hypothesis. This paper will address three such examples: the Caserta's quarries, the Balearic's quarries, and the photographic work of Edward Burtynsky.

\section{Caserta}

The city of Caserta is located 40 kilometers north of Naples. It is home to the Reggia di Caserta, the largest royal palace built in the eighteenth century, a landmark of the region and one of the largest buildings in Europe. The Palace denotes obvious influences of Versailles as a model, including its concept of a highly subordinate nature - la nature forcée.

Such a massive building required the construction of an equally massive infrastructure system, from which one can highlight the monumental aqueduct, an important landscape feature of the region.

But the Casertano landscape is also characterized by a number of aggregates quarries deployed on the slopes of the mountains surrounding the city. Its distribution obeys a specific order, related to geology and topography, independently of the adjacent urban structure, which is modeled by the grid defined by the monumental axis of the palace. The typology and location of the quarries constantly imposes its visual presence in the city.

Some of the abandoned quarries have been the subject of landscape reclamation projects (cf. Berger, 2008), aimed at the installation 
of a plant cover that potentiates their ecological regeneration. Many of them, however, remain as open scars in the landscape, waiting for a comprehensive intervention.

The problem regarding the abandoned quarries around Caserta was the subject of an investigation by Claudio Cajati, Carlos Martí Aris and Raffaele Pastore, whose results were published in 2001. The study constitutes a valuable point of departure regarding the issue of rehabilitation of quarries, framing the specific problem of this Italian region in the general problem of reintegration of void spaces in largescale urban systems.

Their work proposes a geographical-scale approach to the problem, making a broad analysis of the territory, and trying to identify the landscape-construction elements that could serve as methodological operators for the proposed hypothesis. Accordingly, the authors define the contemporary city as an "urban territory" that integrates large voids which maintain the natural soil. Those metropolitan voids, once mere neutral background of the urban life, become a factor of territorial cohesion and community identity. Thus, in contemporary urban territories, landscape systems assume the structural role that was played by the public space systems in the traditional city.

The proposal to recast the relationship between city and nature provides a set of new conceptual tools towards an architecture of the urban environment, requiring a paradigm change that enables new ways of thinking and designing an architecture of the territory. Thus, it refuses architecture as an object, defining it as a system of relations that reveals and highlights pre-existing conditions of reality, which are given new meanings through the mediation of the project (cf. Martí Arís, 2008, p.47).

On the other hand the specificity of the quarries problem implies a project that acts "as a correction factor of the processes that cause the aggression and degradation of the surrounding area. Thus the quarries' problem is placed in a broader context, embracing all the conflicts arising from the territory artificialization process" (Cajati et al., 2001, p.19). Despite this need for correction, the authors nevertheless criticize the unilateral position of environmental protection as an absolute value: "architecture is perceived precisely as the only procedure able to recover the harmonious relationship between man and nature, even in places where natural laws were previously violated" (id., p.18).

Therefore, extinct quarries could result as an opportunity to generate a system of public spaces related to the urban territory to which they belong, confronting its implantation logic to the adjacent urban fabric.

\section{Balearic Islands}

Beyond the ecological and urban integration issues, there is often in the case of quarries a cultural heritage dimension to be considered. When the quarries concern ancient exploits, the issues related to the identity and the memory of local communities are obvious, even though 
such considerations often happens paradoxically late. Such is the case of the sandstone quarries in the Balearic Islands, where nowadays one can witness the efforts of the academic community to identify a specific quarries territory (cf. Salvà Matas, 2014).

The Balearic Islands is a territory characterized by the material culture of the stone. Its insularity and relative isolation, together with its geological features, led to the widespread use of the endogenous sandstone as a building material, from the megalithic period to the present days. Until the mid-twentieth century and the introduction of reinforced concrete, it was practically the only structural material on the islands, extracted in thousands of quarries scattered throughout the territory.

The location of a quarry is always related to two key factors: on the one hand, naturally, to the existence of the mineral that is to be exploited; on the other hand, with the ease of transportation of the extracted material to the place where it is meant to be used. Thus, initially, in the Balearics, the quarries were located preferably in the vicinity of urban areas, or the seaside, in which case the stones would be loaded onto vessels. These locations were only abandoned when the technological progress allowed an ease of transportation, particularly since mid-nineteenth century, with the introduction of the railroad.

The scattering of the quarries throughout the islands' territory caused, until recently, a deficient correspondence between its economical importance and the recognition of its influence on the local identity and culture. Today that deficiency is starting to be corrected.

In Spain, since 1985, the law requires the landfill of extinct quarries. Thus the monumental landscapes that have historically been created in some quarries would be gradually obliterated under tons of dirt and waste of all origins, resulting in possible contamination of the aquifers, and condemning these specific landscapes to oblivion.

In 1994 the quarries of S'Hostal, located in Menorca, characterized by a particular monumentality and beauty, ended its mining activity. The rising awareness of the loss that its disappearance would cause sparked the creation, in 1995, of association LITHICA, at the initiative of architect and artist Laetitia Lara. The association leased the old quarries with the aim of its preservation, rehabilitation and recovery as an historical and ethnological heritage of great artistic and landscape value. The project improved the access conditions to the quarry grounds, opening them to a population that was largely unaware of the cultural values involved. Nowadays the old quarry is a public cultural venue, enabling a specific interpretation of the past of the island community, and fostering a new awareness of their cultural identity.

In the Balearics the "territory manipulated by man (...) involves the generation of a hybrid landscape, built without the prevalence of aesthetics but rather of profit, but which (...) results in quite a striking landscape because of all the direct and indirect reminiscences it has in the identity and memory of the island" (Salvà Matas, 2014, p.236). 
The recognition of the cultural values that arises with the problem of the rehabilitation of quarries allows new understandings of the territory, but can only happen if one improves the visibility of a landscape that is paradoxically absent from the local psycho-geography.

\section{Edward Burtynsky}

The way architecture and landscape is perceived is greatly influenced by the mediation photography allows. It is a tool that helps to define the relations that characterize any given territorial ensemble (whether it's logical, functional, symbolic or analogical relations); to create reference systems; to elect particular action cases studies; and to group and distinguish different phenomena. In the following example, photography will be used as a project of perception.

Edward Burtynsky is a renowned Canadian photographer whose work focuses on industrial society and its relationship with nature altered by man. The main themes of his images are the industrial largescale incursions in landscape, providing views on the consequences of the capitalist lifestyle that are normally inaccessible. Burtynsky often composes his images from a dominant point of view, summoning the sublime condition in the photographs of geographical-scale man-made alterations he captures. The landscapes of Burtynsky challenge us to confront their beauty with their meaning, each playing with attraction and repulsion, catching the eye and defying reason.

Formally its imagery is clearly influenced by Ed Rusha's or the New Topographics', although his line of thought is rooted in the environmental movement. His work is an investigation on the relationship between landscape photography and the environmental problem, in Peter Blake's line or the Sierra Club's. However, despite this affiliation, his discourse often moves away from the pessimism that usually characterizes the environmental movements: Burtynsky's images are beautiful, and the artist assumes the guilty pleasure in contemplating the changes brought about by man in nature. The aporetic condition of Burtynsky's work makes it profoundly contemporary.

In 1991, disquieted by a thought about a stone-clad building, Burtynsky started a photographic research project that he entitled Quarries (Burtynsky, 2007). The research would only end in 2006, when the artist visited Estremoz Anticline.

Searching around the world for an imagined landscape that would be, in a certain sense, the negative of the stone-made cities he knew, the research culminated when he made an image of a quarry in Vila Viçosa: "Turn the image Iberia Quarries \#3 upside down and there it finally is the inverted ziggurat that he had so long imagined. His quarry work was complete." (Burtynsky, n.d.).

Burtynsky understands the Alentejo quarries as part of the broad history of industrialization, and summons them to the problematic that arises from the relationship between the exploitation of raw materials 
and the landscape. In this sense, he reveals a hidden evidence: this is a local problem, but it is part of a wider global civilizational process. This revelation grants a specific, aesthetic and cultural value to this landscape, and is one of the keys to the interpretation of the problem.

\section{Final notes}

The quarries territory of Estremoz Anticline is difficult to catalog. Being largely excluded from urban dynamics surrounding it, one could confuse it with an expectant, semi-abandoned, and largely forgotten land - in other words, a terrain vague (cf. Sola-Morales, 2002). Certainly it shares with those territories a condition of exception, an evocative potential, a promise of encounter between different orders, and even, to large extent, a state of abandonment; yet, unlike those territories, its concrete meaning is fully defined: these quarries are a territorial and economic device, integrated in international production systems, consuming a particular topography and turning it into marble blocks to be sold in global markets.

The problem presented with a projectual intervention in this territory is still an open one, but it appears to integrate two key dimensions to be surveyed: what to do with what is left after the quarrying is abandoned; and how to integrate such a territorial device in the near urban system. One must, therefore, try to find an operating means of including it in a broader system of territorial collective references, by interpreting its symbolic meaning, its heritage value, and its sense of public use.

A project for the quarries landscape of Estremoz Anticline should always start from a holistic approach to the issues that arise with such a specific problem. The construction of a program for such intervention should abide with the ideas of temporality, change, and alteration of the meaning of this landscape. It should embrace the uncertainty of unknown futures, which is usually absent from current territorial planning.

A valid starting point to address such project is the opportunity of a symbolic recovery of exhausted productive places that lost their original reason for being, and its integration in a new kind of territorial system. These systems have always been determinant in the occupation of the territory and in the construction of the landscape, and its transformation will happen, as always, by the semantic and syntactic change of the territorial facts that constitute them. Such territorial facts can form matrices of new urban centralities, public places in the territory, or merely singular or symbolic locations in the landscape.

The aggregation of quarries in Estremoz Anticline constitutes a territorial system of geographical scale paradoxically absent from the adjacent urban system. Any territorial architecture project that addresses this area should also start by acknowledging that condition, which is simultaneously a programmatic opportunity. This specific landscape is perhaps the most significant territorial fact of all three

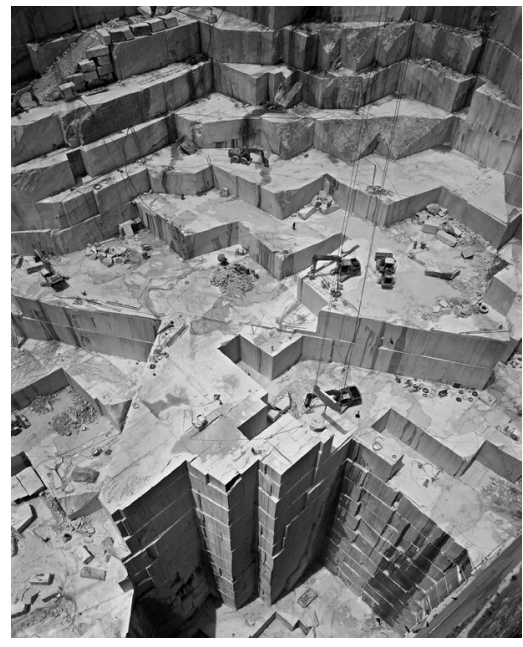

6. Iberia Quarries \# 3, Cochicho Co., Pardais, Portugal. Photo @ Edward Burtynsky, courtesy Nicholas Metivier Gallery, Toronto/Admira Photography, Milan. Original in colour. 
municipalities to which it belongs. Nevertheless, the problem was never addressed in an integrated way as a specific asset of this region, with the potential to distinguish it from the set of low-density Portuguese territories.

This work frame suggests, therefore, the definition of an intermunicipal, strategic project of territorial acupuncture, which combines the economical value of the quarrying industry with the cultural value of this new type of heritage, and contributes to the creation of a new territorial system, and the transformation of this cultural landscape in its physical and conceptual dimensions.

\section{References}

Berger, A. (Ed.). (2008). Designing the reclaimed landscape. New York: Taylor \& Francis.

Burtynsky, E. (2007). Quarries. Göttingen: Steidl.

Burtynsky, E. (n.d.). Homepage. Retrieved September 8th, 2015 from: http://www.edwardburtynsky.com/ site_contents/Photographs/Quarries.html

-

Cajati, C., Martí Arís, C. \& Pastore, R. (2001). Luoghi pubblici nel território: Una proposta per le cave del casertano. Nápoles: Giannini.
Maciel, M. J. (1998) Arte romana e pedreiras de mármore na Lusitânia: novos caminhos de investigação. In Revista da Faculdade de Ciências Sociais e Humanas (n. ${ }^{\circ} 11$, pp. 233-245). Lisboa: Edições Colibri.

Marti Arís, C. (2008). Llocs públics en la natura. Girona: Universitat de Girona.

Moura, A. C., Carvalho, C., Almeida, I. A., et al. (2007). Mármores e calcários ornamentais de Portugal. [n.p.].
Salvà Matas, C. (2014). El descobriment d'un paisatge desconegut: Les pedreres de marès, rastres oblidats en el territori de Mallorca. In Bolletí de la Societat Arqueològica Lulliana (n. $\left.{ }^{\circ} 70, \mathrm{pp} .235-255\right)$. Palma de Maiorca: Societat Arqueológica Lul-liana.

Sola-Morales, I. (2002). Territorios. Barcelona: Editorial Gustavo Gili, S.A. 